\title{
Integrated design of biorefineries based on spent
}

\section{coffee ground}

\author{
Manuel Taifouris ${ }^{a}$, Marcos L. Corazzab ${ }^{\text {, Mariano Martín }}{ }^{a 1}$ \\ a Department of Chemical Engineering, University of Salamanca. Plz. Caídos. 1-5. 37008. Spain \\ ${ }^{b}$ Department of Chemical Engineering, Federal University of Paraná (UFPR), 100 Av. Francisco H. dos \\ Santos: 8153 1-980 Curitiba, State of Paraná, Brazil
}

\section{Abstract}

The circular economy concept applied to the management of Spent coffee Ground is an opportunity to obtain a portfolio of high added-value products and reducing the environmental impact while increasing the profitability and reducing the energy consumption of the soluble coffee production process. $A$ systematic analysis of the alternatives is performed to unveil integration opportunities and find synergies aiming at the optimal set of processes and products. In this work, five products, dry natural extract, dry natural pigment for the textile industry, biogas, digestate, and electrical energy, throughout 3 different processes are considered. A systematic techno-economic analysis of all processes is carried out and two processes were found economically promising, the production of power and the production of natural extract and pigment. The production of natural pigment and natural extract is the most profitable process with a profit 10 times greater than the production of electrical energy. The operation and investment costs are 4.25 MM€/year and 14.1 MM€ respectively. The use of SCG to produce biodiesel is discarded after the analysis. Therefore, it is possible to achieve economic benefit from the treatment of this waste.

Keywords: Spent coffee ground, biorefinery, circular economy, added value products

\footnotetext{
${ }^{1}$ Corresponding autor: mariano.m3@usal.es
} 


\section{Introduction}

Society faces 3 problems, the need for energy and food and the high production of waste. The three represent not only a demand, supply, and management issue but they also show a large environmental impact, which is increasingly aggravated due to the growth of the world's population. In particular, the effect of uncontrolled waste production represents already a challenge, and society is becoming aware and concerned. As a result, more restrictive legislation on waste generation is being approved ${ }^{1}$, favoring the development of a circular economy and the bioeconomy. The main idea is to valorize the waste generated in a biological process into high value-added products that are used as raw materials for other industries or are directly sold to the final consumer ${ }^{1}$. Some examples of added value products that can be obtained from waste are essential oils ${ }^{2,3}$ and natural extracts ${ }^{4}$. The bioeconomy concept applied to the food industry has not only economic benefits such as the creation of direct and indirect jobs and the improvement of the competitiveness of production processes but also environmental benefits ${ }^{3}$. This usually involves the integration of different technologies such as extraction, filtration, hydrolysis, fermentation, transesterification, or pyrolysis. Among the products of the food industry, one stands out above the rest, coffee. Coffee is the second most important consumer product after oil ${ }^{5}$ with a production of 10.16 billion kilograms between 2018 and $2019^{6}$. Its production is mainly concentrated in countries such as Brazil, Vietnam, Colombia, Indonesia, Ethiopia, India, and Honduras, with Brazil being the largest coffee exporter in the world ${ }^{7}$. During the coffee production processes, a large amount of waste is generated, standing out among them the Spent Coffee Ground (SCG) and the Coffee Silver Skin (CSS) ${ }^{5}$. In the coffee industry, $650 \mathrm{~kg}$ of SCG per ton of green coffee beans and 2 kilograms per kilogram of soluble coffee produced are generated 8 .

In the countries mentioned above, current environmental laws are more permissive than in the case of Europe or the US, so this type of waste ends up in landfills, incinerated, or used as compost. This causes a series of environmental problems such as soil contamination ${ }^{9}$, due to the presence of toxic substances such as caffeine or other polyphenols, the production of greenhouse gases such as $\mathrm{CH}_{4}$ and $\mathrm{CO}_{2}$, due to the decomposition of organic matter, and the release of large amounts of $\mathrm{CO}_{2}$ in incineration processes. Alternatively, SCG can be used to produce a wide variety of high added-value products due to its 
composition. The use of the residue to produce these high added-value products does not only reduce its environmental impact but provides additional value, closing the life cycle, transforming the waste from one industry into the raw material for another, pursuing the goal of zero waste emissions leading to a truly circular economy. Some authors have studied the use of SCG to produce different types of biofuels, such as biodiesel and bioethanol ${ }^{10,11}$, biogas ${ }^{12}$, bio-oil ${ }^{13}$ and pellets ${ }^{14}$; food supplements and biocomponents for the pharmaceutical and cosmetic industries, such as caffeine, antioxidants, and phenolics ${ }^{15}$; natural extracts 4,16 ; additives for industry, such as tannins ${ }^{17}$ or polymers such as polyhydroxyalkanoates (PHAs) 18; fertilizer production for some types of crops ${ }^{19}$ and energy production ${ }^{20}$. However, these are experimental studies that only evaluate the production yields of various products but do not carry out techno-economic studies of the entire process. In addition, techno-economic analyses are focused on the production of specific products ${ }^{4,21}$. The use of SCG for the production of added value products represents an opportunity to reduce the environmental impact of the coffee industry, reducing the energy consumption and waste generation, while improving its economics. The selection of the portfolio of products requires a systematic analysis of the alternatives to unveil the synergies and integration opportunities.

In this work, mathematical optimization techniques are used for the design of a process that transforms the Spent Coffee Ground into a portfolio of products including high-added value ones. The treatment of coffee wastes must be economic and environmentally conscious and with the final aim of integrating this process as a section of a soluble coffee production plant, favoring the circular economy. Five products, dry natural extract, natural pigment for the textile industry, biogas, digestate, and electrical energy, and 3 processes are considered. This work corresponds to the conceptual level design of the facility constituting a previous step to the design and construction of a biorefinery providing a guide towards the use of SCG. The rest of the paper is organized as follows. In section 2, the mathematical optimization model is developed, including the modeling of the process with the energy and mass balance, considerations, and diagrams. An economic analysis is carried out as well. In section 3 , the model is applied for a representative industrial case and the results are presented and in section 4, the conclusions and future work are discussed. 


\section{Process description}

In this section, the superstructure of alternative processes is described and shown in Figure 1. Three main processes and two sub-processes derived from Process 1 (Process A1 and Process A2) are considered for the valorisation of the SCG. The modeling of the processes is carried out using mass and energy balances, phase equilibria, experimental yields, and rules of thumb to describe the yield, and performance of each one of the units ${ }^{22}$. Process 1 consists of an extraction and filtration system for the production of a natural coffee extract of high added value. This process generates two residues that are valorised through anaerobic digestion (Process A1) to produce biogas and digestate, and a filtration and drying process (Process A2) to produce natural pigment. Process A1 and Process 2 use the same technology, but the difference is the raw material. SCG is used as a raw material for Process 2 while process A1 uses the residue from the decanter of Process 1 . Finally, Process 3 uses the SCG to produce electrical energy using a boiler and a steam turbine. The processes are modelled following an equation based approach in GAMS.

In the design of the superstructure, the integration of energy, and water is considered (see Figure 1). The energy required for the anaerobic digestion, filtration and drying processes is generated within the facility through an auxiliary process. The processes that require dry raw material are discarded due to the cost of energy involved in the drying stage of raw material with $60 \%$ humidity. The composition of the raw material is shown in Figure 2. This composition can be obtained from the mass balances shown in the literature. ${ }^{4}$ In addition, another important piece of information to model the mass balances is the average density of the solids of the SCG. Given the density of the SCG and its water content ${ }^{23}$, the average density of the solids is determined $\left(1.329 \mathrm{~kg} / \mathrm{dm}^{3}\right)$. Besides, the density of citric acid $\left(p_{a c}\right)$ is $1.66 \mathrm{~kg} / \mathrm{dm}^{3}$. In that work, the process was evaluated at laboratory and pilot plant scales. 


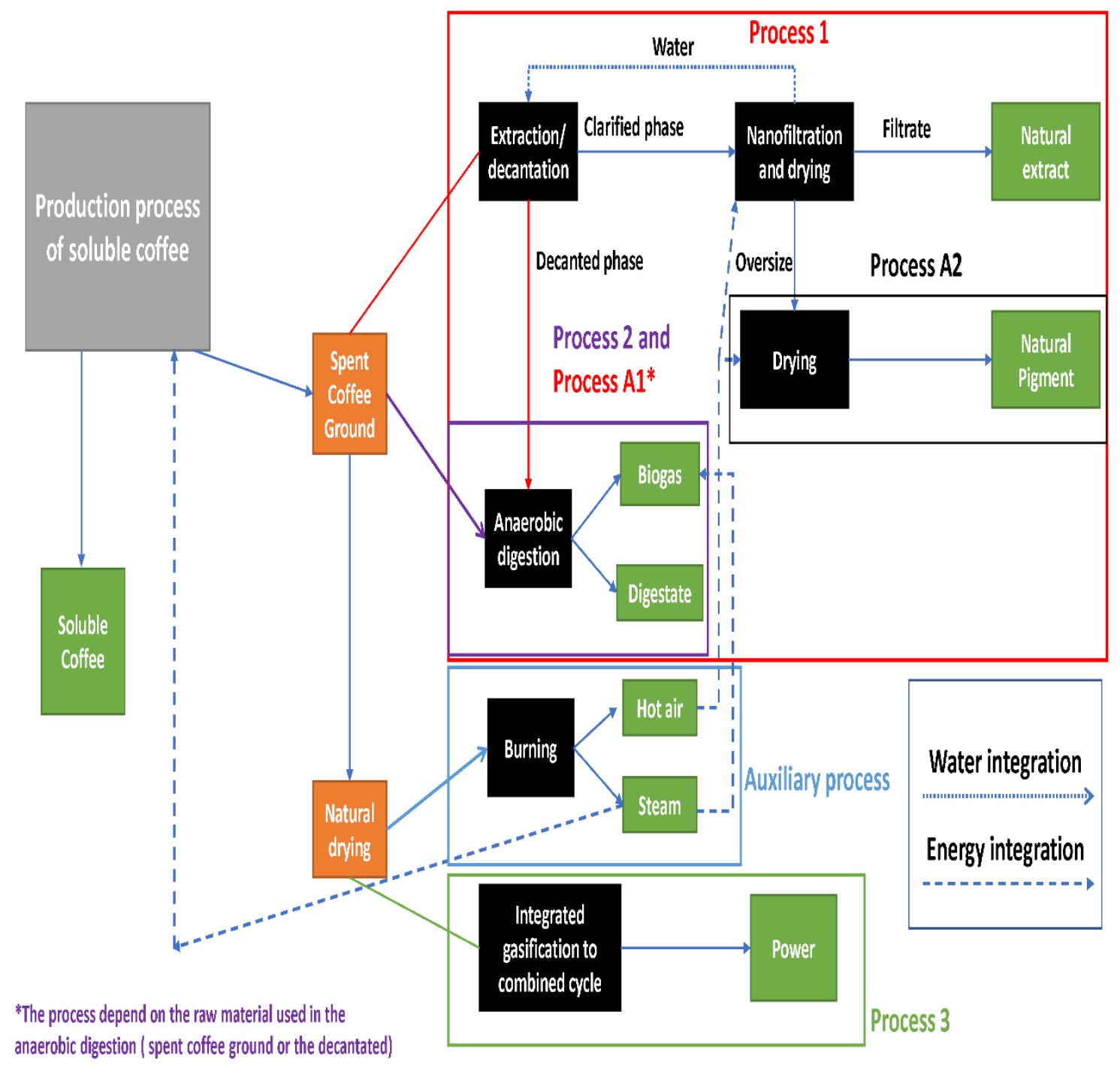

Figure 1.- Superstrucure for the use and integration of Spent coffee ground 


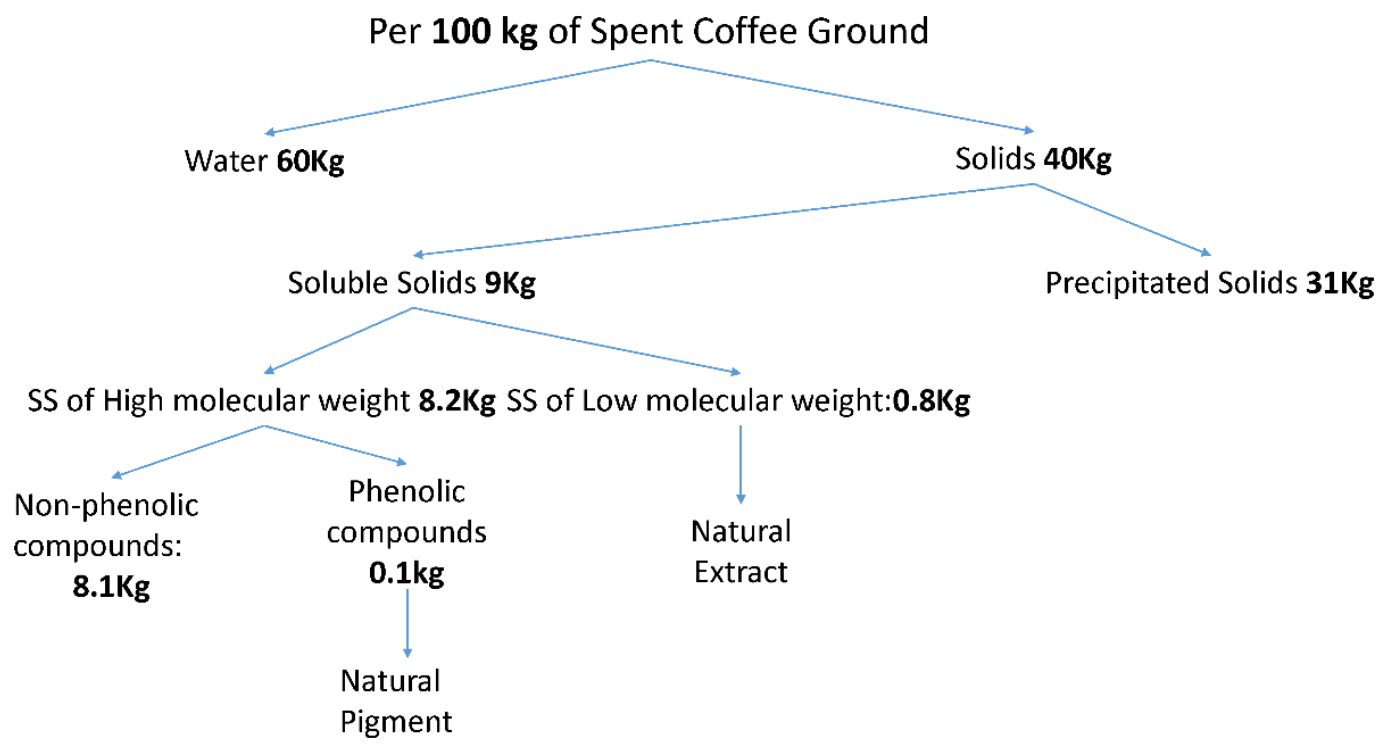

Figure 2.- Composition of the Spent Coffee Ground.

\subsection{Process 1: Production of natural extract}

The details of Process 1 can be seen in Figure 3. Among all the products considered in this work, the natural extracts of the spent coffee ground are the ones with the highest added value. 


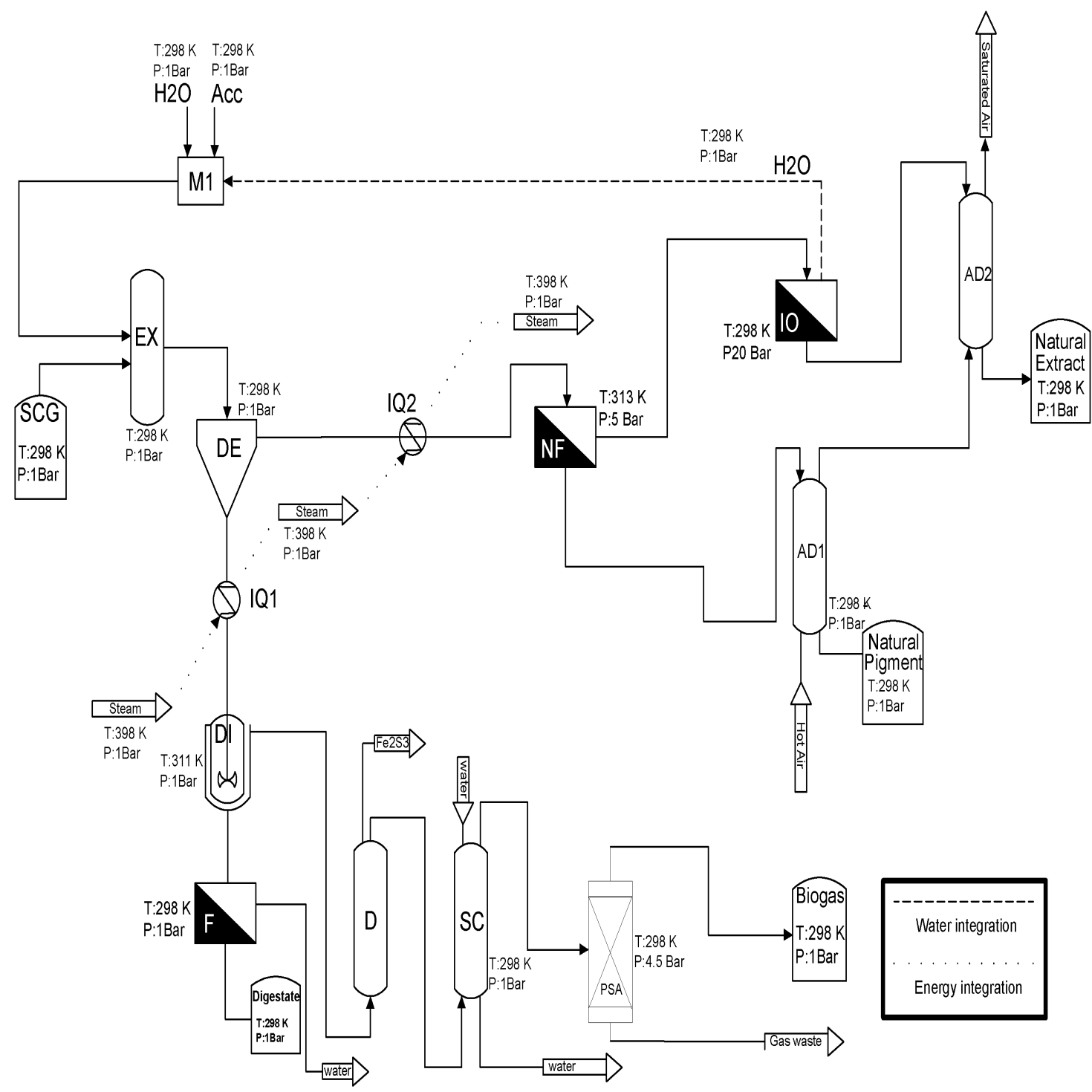

Figure 3.- Flowsheet diagram of Process 1 - Production of natural extract from SCG.(M: Mixer)

The composition of the SCG (Figure 2) is obtained by analyzing the mass balances from the literature ${ }^{4}$. Besides, some considerations must be adopted. It is assumed that the raw material has a humidity percentage of $60 \%{ }^{4}$. The mass ratio of the extraction medium (water and a solution of $3 \mathrm{~g} / \mathrm{L}$ acid citric) with respect to the raw material is 44

After the extraction process (EX), the solids are distributed between the decanted and clarified phase in the decanter (DE). The mass ratio between the clarified phase and the SCG fed to Process 1 is 3.24 . Therefore, the mass flows of the clarified phase $\left(F_{C L A}\right)$ and the decanted phase $\left(F_{D E C}\right)$ are calculated from the raw material $\left(\mathrm{F}_{\mathrm{RM}}\right)$ by Eqs. (1) and (2). 


$$
\begin{aligned}
& F_{C L A}=3.2 F_{R M} \\
& F_{D E C}=1.8 F_{R M}
\end{aligned}
$$

In addition, the volume of the clarified phase is also reported, so its density can be calculated (pcLA) = $\left.1.01 \mathrm{~kg} / \mathrm{dm}^{3}\right)$. This information allows obtaining the composition of soluble solids, water, and citric acid of the clarified stream since the amount of precipitated solids ( $\left.\mathrm{F}_{\mathrm{DECPS}}\right)$ can be estimated using the consideration explained in the section describing Process 2 (Table 1), and the SCG composition $\left(\mathrm{F}_{\mathrm{RM}}\right)$ is known. The mass balances of water, precipitated solids, and acid citric in the decanted phase is shown by Eq. (3). Besides, the concentration of citric acid is $3 g / L$ with respect to the amount of water in each phase (Eqs.(4) and (7)).

$$
\begin{gathered}
F_{D E C_{H_{2} \mathrm{O}}}+F_{D E C_{A c}}+F_{D E C_{p s}}=F_{D E C} \\
F_{D E C_{A c}}=0.003 \cdot F_{D E C_{H_{2} \mathrm{O}}}
\end{gathered}
$$

In the case of the clarified phase, the mass flows are obtained by Eqs. (5)-(6):

$$
\begin{gathered}
F_{C L A_{s s}}=F_{R M_{T S}}-F_{D E C_{p s}} \\
F_{C L A_{H_{2} \mathrm{O}}}+F_{C L A_{A c}}+F_{C L A_{s s}}=F_{C L A} \\
F_{C L A_{A c}}=0.003 \cdot F_{C L A_{H_{2} \mathrm{O}}}
\end{gathered}
$$

Thus, if the density of the clarified phase is known, the average density of the solids can be corrected. This is shown in Eq.(8).

$$
F_{C L A} \cdot \rho_{C L A}=F_{C L A_{H_{2} O}} \cdot \rho_{H_{2} O}+F_{C L A_{A c}} \cdot \rho_{A c}+F_{C L A_{s s}} \cdot \rho_{s s}
$$

The density of the solids can be calculated and used in the rest of the mass balances. This density determines the distribution of the amount of water between the different phases in the nanofiltration process but the amount of solids in each phase is known and there is a large amount of water in both 
phases. Therefore, the error in the approximation is negligible. Precipitated solids $\left(F_{D E C_{p s}}\right)$ are the first type of waste generated in the processing of SCG and are treated by Process A1. The steam to heat-up the stream $\left(\mathrm{IQ}_{2}\right)$ before the nanofiltration process $(\mathrm{NF})$ is generated within the plant by an auxiliary process that uses a fraction of the SCG. IQ is a partial condenser and the energy balance is presented in Eq. (9).

$$
\sum_{i} F_{C L A_{i}} \cdot c p_{i}\left(40^{\circ} \mathrm{C}-25^{\circ} \mathrm{C}\right)=\left(\mathrm{F}_{\text {steam }_{\text {in }}}-\mathrm{F}_{\text {steam }_{\text {out }}}\right) \cdot \lambda_{\mathrm{H} 2 \mathrm{O}}
$$

Where $\mathrm{cp}_{\mathrm{i}}$ is the heat capacity of each compound of the clarified stream and $\lambda_{\mathrm{H} 2 \mathrm{O}}$ is the latent heat of the water. In this case, the heat capacity of the liquid water is used since this is the main compound of the stream.

In the nanofiltration process, low molecular weight soluble solids (i.e. caffeine) are separated from high molecular weight solids (i.e. tannins) to adjust the antioxidant properties of the final product and, thus, that product can be sold as a natural coffee extract. Besides, the citric acid is retained in this stage 4 .

The amount of solids that go through the nanofiltration process, FPERssm, is determined using the data on the final product presented by the literature ${ }^{4}$. The production yield with respect to the SCG feed and the humidity of the final product are $0.8 \%$ and $5.9 \%$, respectively. Therefore, the amount of solids in the final product can be calculated as described below. Between the final product and the nanofiltration process, there is only reverse osmosis (IO) and a drying process (in both processes, only the water is removed). Therefore, the amount of solids in the final product is the same as in the permeate of the nanofiltration process. The retained solids, $F_{\text {RENsshm, }}$ can be calculated as the difference between the total solids before the process of nanofiltration, $F_{\text {CLAss, }}$ and the solids in the permeate stream (FPERssIm) (Eq. (10)). The solids retained $\left(F_{R E N_{s s h m}}\right)$ are the second type of waste generated in Process 1 and are treated at Process A2. The volume of the retentate is given by the concentration factor, $\mathrm{CF}_{\mathrm{NF}}$, with a value of 7.5 in the literature 4 , (Eq.(11)) and the mass balance of the compounds of the retentate can be calculated by Eqs. (12)-(14). 


$$
\begin{gathered}
F_{R E N_{s s h m}}=F_{C L A_{s s}}-F_{P E R_{s s l m}} \\
V_{R E N}=\frac{V_{C L A}}{C F_{N F}} \rightarrow V_{R E N}=\frac{F_{R E N}}{\rho_{R E N}} \rightarrow F_{R E N}=V_{R E N} \cdot \rho_{R E N} \\
F_{R E N_{H_{2} O}}+F_{R E N_{A c}}+F_{R E N_{s s h m}}=F_{R E N} \\
F_{R E N_{H_{2} 0}} \rho_{H_{2} O}+F_{R E N_{A C}} \rho_{A c}+F_{R E N_{s s h m}} \rho_{s s}=F_{R E N} \cdot p_{R E N} \\
F_{R E N_{A c}}=F_{C L A_{A C}}
\end{gathered}
$$

In the case of the permeate, the amount of each compound i can be calculated as the difference between the amount of the compounds of the retentate and the clarified phase of the decanter (Eq.(15)).

$$
F_{P E R_{i}}=F_{C L A_{i}}-F_{R E N_{i}}
$$

The high molecular weight solids are treated in Process A2, while the low molecular weight solids are dehydrated in a reverse osmosis process and dried to reduce the amount of water down to $5.9 \%$, using a hot air dryer (AD) fed with a stream of flue gas generated in an auxiliary process. The concentration factor $\left(\mathrm{CF}_{\mathrm{O}}\right)$ is $30^{4}$, in the case of the reverse osmosis process (Eq. (16)). In this case, only the water is removed (Eq.(17)) in the permeate stream ( $F_{\text {oIP }}$ in the reverse osmosis process.Eqs. (18)-(20) are used to evaluate the mass balances between the permeate stream and the rejected stream $\left(F_{\mathrm{OIR}}\right)$ and their componets.

$$
\begin{aligned}
& V_{\text {OIR }}=\frac{V_{P E R}}{C F_{\text {OI }}} \rightarrow V_{\text {OIR }}=\frac{F_{\text {OIR }}}{\rho_{\text {OIR }}} \rightarrow F_{\text {OIR }}=V_{\text {OIR }} \cdot \rho_{\text {OIR }} \\
& F_{\text {OIP }}=F_{O_{\mathrm{H}_{2} \mathrm{O}}} \\
& F_{P E R}=F_{O I P}+F_{O I R} \\
& F_{\text {OIR }}=F_{\text {OIR }_{H_{2} O}}+F_{\text {OIR }_{\text {sshm }}} \\
& F_{\text {OIR }_{H_{2} 0}} \rho_{\mathrm{H}_{2} \mathrm{O}}+F_{\text {OIR }_{\text {sshm }}} \rho_{s s}=F_{\text {OIR }} \cdot p_{\text {OIR }}
\end{aligned}
$$


In the drying processes, only the water is exchanged between the streams. In the case of the drying process of the natural pigment (AD1), the mass balances are shown by Eqs. (21)-(23). Eqs.(24)-(26) are used to model the drying process of the natural extract (AD2).

$$
\begin{gathered}
F_{R E N}+F_{F G I A D 1}=F_{N P}+F_{F G O A D 1} \\
F_{R E N_{H 2 O}}-F_{N P_{H 2 O}}=F_{F G O A D 1_{H 2 O}}-F_{F G I A D 1_{H 2 O}} \\
F_{N P_{H 2 O}}=0.1 \cdot F_{N P} \\
F_{O I R}+F_{F G I A D 2}=F_{N E}+F_{F G O A D 2} \\
F_{\text {OIR }_{H 2 O}-F_{N E_{H 2 O}}=} F_{F G O A D 2_{H 2 O}}-F_{F G I A D 2_{H 2 O}} \\
F_{N E_{H 2 O}}=0.059 \cdot \mathrm{F}_{\mathrm{NE}}
\end{gathered}
$$

Based on the mass balances presented and described above, Process 1 is modelled within the superstructure.

\subsection{Process 2 and process A1: Production of biogas and digestate.}

The same technology (anaerobic digestion) is used in both processes to produce biogas and digestate. The difference is the raw material they use. In Process 2, SCG is used as raw material while Process A1 uses the precipitated solids from the decanter of Process 1 (see Figure 1). The process flow diagram of both processes can be seen in Figure 4. The composition for the SCG is taken from the literature ${ }^{12}$, but in the case of precipitated solids, their composition must be estimated, since the composition is not indicated in the experimental study ${ }^{4}$. The initial composition of the SCG and the following considerations are used to estimate it.

- The nitrogen present in SCG is divided into proteins and non-protein nitrogen (NPN. The proportion of the nitrogen in the SCG is $54.34 \%$ in the form of protein and $45.66 \%$ in the form of NPN ${ }^{24}$. Proteins are insoluble because, after the production of the soluble coffee, the protein suffers a denaturation and association with cell wall arabinogalactans ${ }^{25}$. In addition, $62.57 \%$ of the NPN is soluble in water ${ }^{24}$. Considering that it is distributed in the same way in the water of the clarified phase and the water of the precipitated phase and that the ratio of the amount of 
water in the clarified phase with respect to that in the precipitated phase is $2.11^{4}, 32.25 \%$ of the soluble NPN is retained by the precipitate.

- Most carbohydrates are formed by cellulose, hemicellulose, and lignin ${ }^{25}$. These compounds are insoluble in water ${ }^{26}$ under the process conditions ( 1 bar and $25^{\circ} \mathrm{C}$ ), so it is considered that the carbohydrate after the decantation process is the same that the carbohydrate in the raw material.

The composition of the precipitated solids is shown in Table 1.

Table 1.- Amount of the precipitated solids $(31.01 \mathrm{~kg})$

\begin{tabular}{|c|c|}
\hline Compound & Amount (kg) \\
\hline Ash & 0.484 \\
\hline Lignin & 6.132 \\
\hline Protein & 2.667 \\
\hline Lipids & 5.600 \\
\hline Carbohydrates & 14.838 \\
\hline NPN (soluble) & 0.452 \\
\hline NPN (insoluble) & 0.839 \\
\hline
\end{tabular}

This composition is used to model the anaerobic digestion of the precipitated solids. The model of the digester is formulated as an input-output model within the optimization framework. The reactor yield is obtained by running a detailed kinetic model of the process ${ }^{27}$. In this model, an empirical formula of proteins, carbohydrates, and lipids is considered to calculate the mass and energy balances.

Lipids

$$
\mathrm{C}_{57} \mathrm{H}_{104} \mathrm{O}_{6}+23.64 \mathrm{H}_{2} \mathrm{O}+1.4534 \mathrm{NH}_{3} \Rightarrow 36.3665 \mathrm{CH}_{4}+13.34 \mathrm{CO}_{2}+1.45 \mathrm{C}_{5} \mathrm{H}_{7} \mathrm{NO}_{2}
$$

Carbohydrates

$$
\mathrm{C}_{6} \mathrm{H}_{10} \mathrm{O}_{5}+0.351 \mathrm{H}_{2} \mathrm{O}+0.2163 \mathrm{NH}_{3} \Rightarrow 2.459 \mathrm{CH}_{4}+2.4592 \mathrm{CO}_{2}+0.2163 \mathrm{C}_{5} \mathrm{H}_{7} \mathrm{NO}_{2}
$$

Protein

$$
\mathrm{CH}_{2.03} \mathrm{O}_{0.6} \mathrm{~N}_{0.3} \mathrm{~S}_{0.001}+0.31 \mathrm{H}_{2} \mathrm{O} \Rightarrow 0.4060 \mathrm{CH}_{4}+0.422 \mathrm{CO}_{2}+0.0299 \mathrm{C}_{5} \mathrm{H}_{7} \mathrm{NO}_{2}+0.001 \mathrm{H}_{2} \mathrm{~S}+0.2637 \mathrm{NH}_{3}
$$




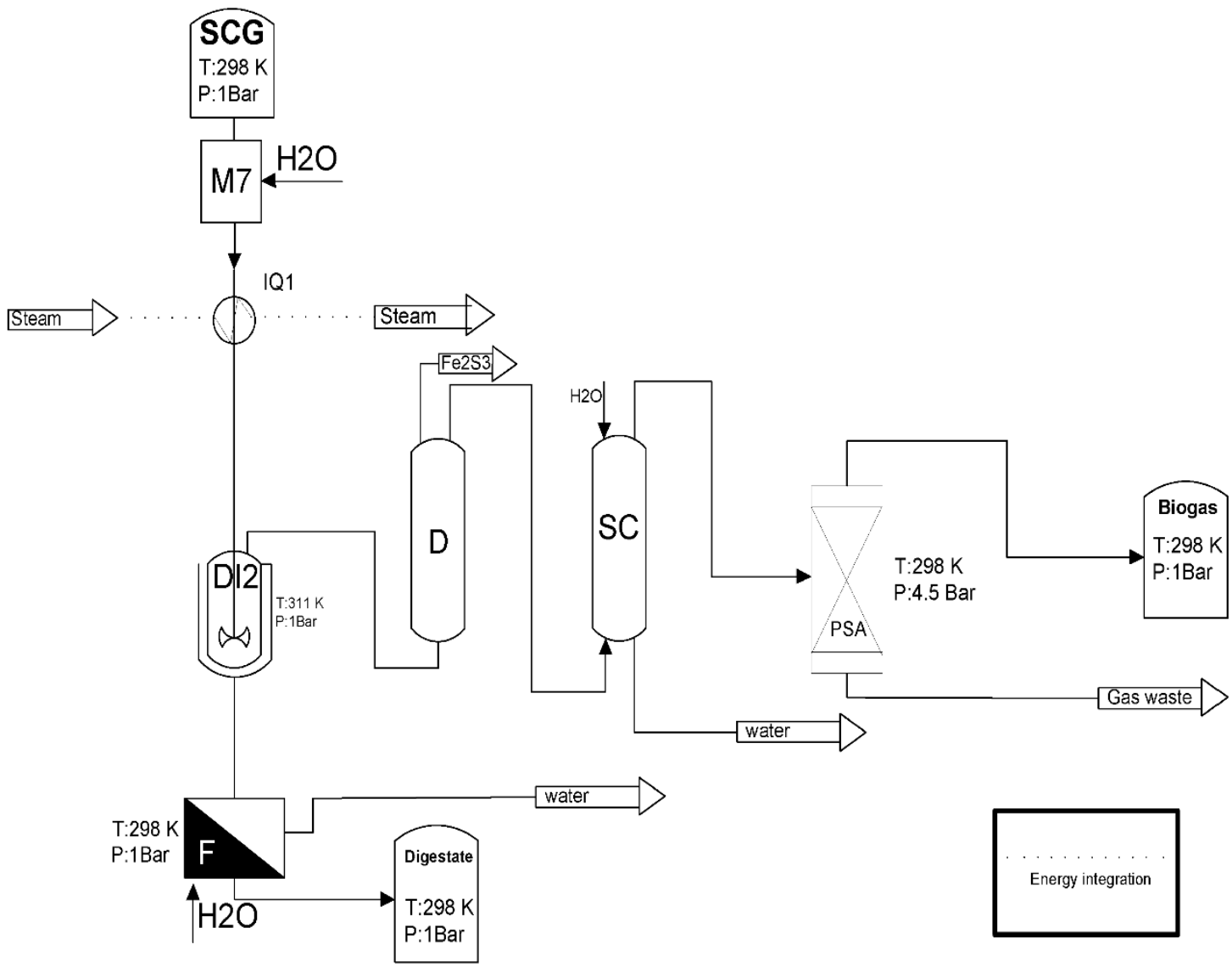

Figure 4.- Flowsheet diagram of Processes A1 and 2: Production of biogas and digestate.

The kinetics is modelled based on the following considerations ${ }^{27}$.

- The kinetics is adjusted to a first-order reaction where the limiting phase is hydrolysis.

- The reaction is carried out in a stirred thermostated batch reactor to keep the temperature constant.

The kinetic constants are obtained by fitting the kinetic model to the experimental data ${ }^{12}$. Therefore, the stream has to be heated up to $311 \mathrm{~K}$ (IQ1 in process 2 ( see Figure 4) and in process A1 (see Figure 3)).The rest of the considerations and the kinetic model can be seen in the previous work. ${ }^{27}$ The residence time must be equal to or less than 21 days since the reference study only has data until that day 
to avoid extrapolation errors. Only a fraction of the raw material is used, $\mathbf{8 0} \%$ at the most. The profile of the concentration of the components involved in the reaction in the time can be seen in Figure 5 .

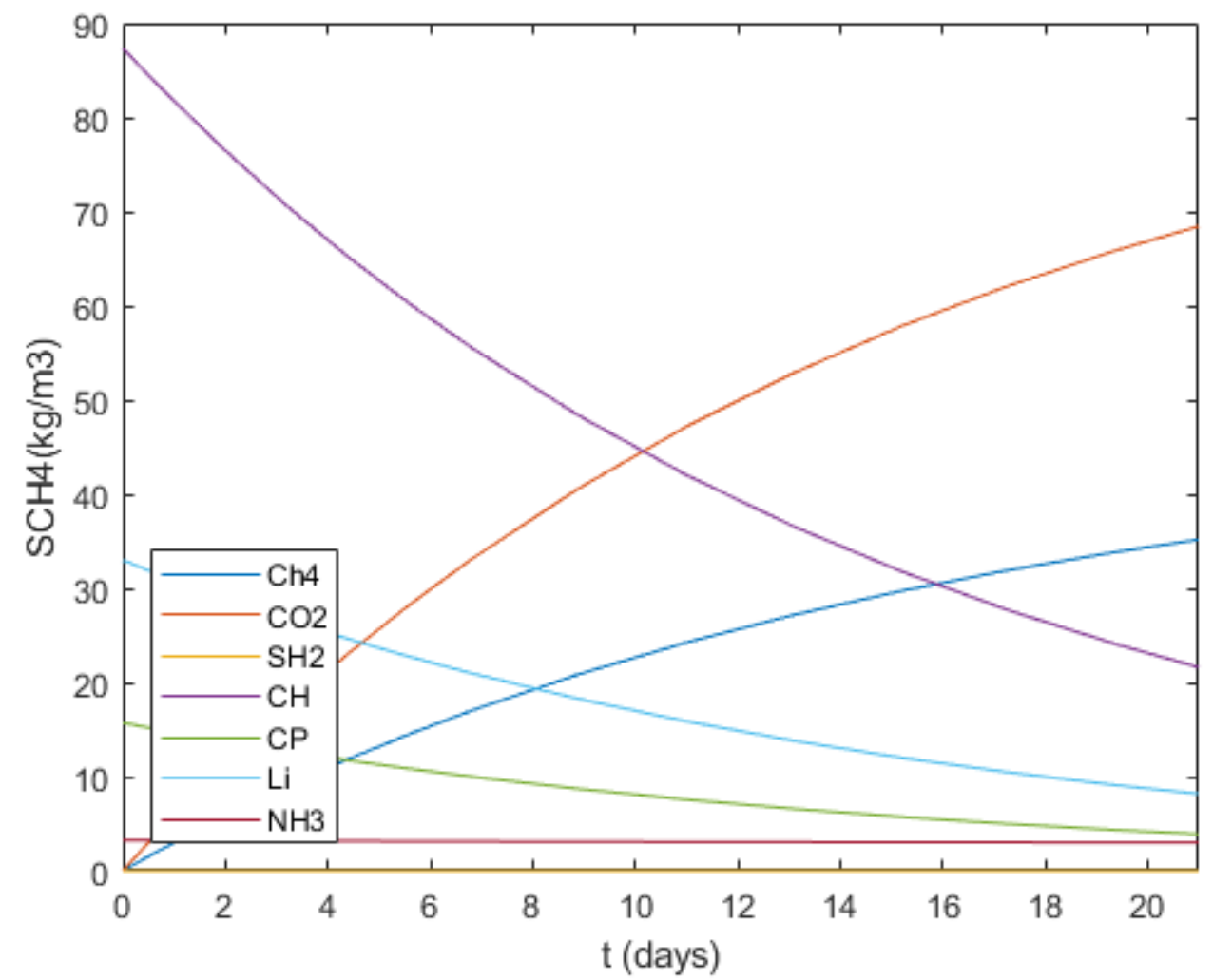

Figure 5.- Profile of the chemical species along the anaerobic digestion

Thus, the reaction yield and its kinetics, the Dalton's and Raoult's principles, as well as Antoine's equation, are used to determine the gas composition exiting the digester (DI). This approach was chosen considering a large amount of liquid phase water compared to other gases. The ratio between the molar fraction in the liquid phase and the gas phase is given by Eq. (27).

$$
\frac{1}{10^{A-\frac{B}{C+T}} \cdot \mathrm{X}_{\mathrm{i}}}=y_{i}
$$

A bed of $\mathrm{Fe}_{2} \mathrm{O}_{3}(\mathrm{D})$ is used to remove the $\mathrm{H}_{2} \mathrm{~S}$, a scrubber (SC) is used to reduce the amount of ammonia down to $5 \%$, and a pressure swing adsorption (PSA) is used to remove the rest of the ammonia, the water and $95 \%$ of the $\mathrm{CO}_{2}$ of the biogas ${ }^{28}$. A granular filter $(\mathrm{F})$ is installed to dry the digestate ${ }^{27}$. The water 
consumption of the scrubber is $24.55 \mathrm{~m}^{3}$ per ton of biogas, while in the case of the filter it is $0.008 \mathrm{~m}^{3} \mathrm{per}$ ton of digestate for the cleaning cycle.

\subsection{Process A2: Production of Natural pigment}

The flowsheet of process A2 can be seen in Figure 6 . This process is fed by the solids retained in the nanofiltration process. These solids are concentrated in tannins. The size of these particles is larger than the ones containing caffeine and can be retained in the nanofiltration process ${ }^{4}$. Since SCG tannins can be used to dye different textiles with brown color ${ }^{29}$, this product can be sold as a natural pigment. The concentration of tannins in these solids was not provided in the experimental study, but the performance to dye a textile sample can be related to the total amount of phenolic components in solution. The amount of phenolic component needed to correctly dye a gram of textile material is $0.012 \mathbf{g} / \mathbf{g}$ textile sample 29 .

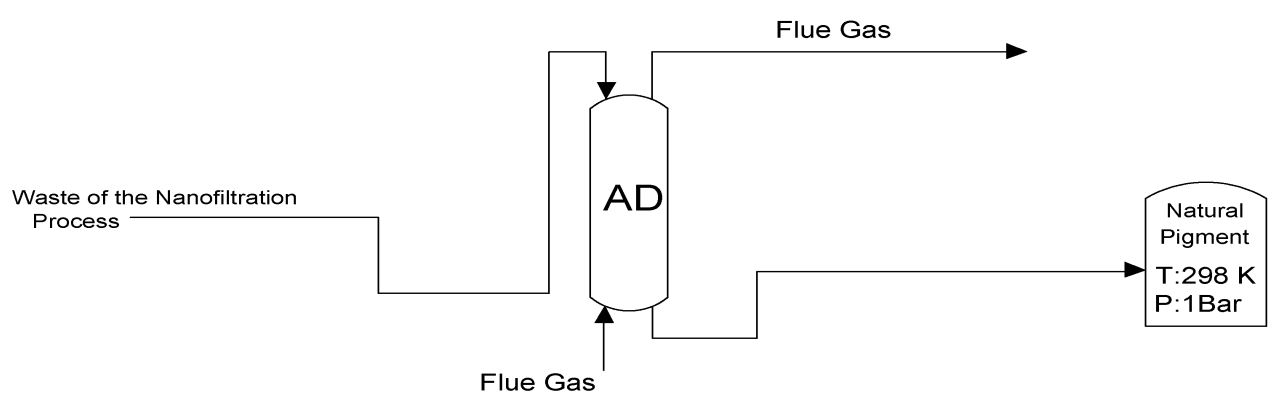

Figure 6.- Flowsheet diagram of Process A2: Production of Pigment

The natural pigment is also composed of non-phenolic compounds and a percentage of water. Therefore, the actual ratio is $0.78 \mathrm{~g}$ Natural Pigment / $\mathrm{g}$ textile. This data will be particularly important to estimate the sale price of this product.

The ratio between the phenolic components after the extraction process and the dry raw material was experimentally determined (Eq.(28)) ${ }^{4}$.Furthermore, the yield to natural extract production and the amount 
of phenolic components in the final product are known. Therefore, the amount of phenolic compounds can be calculated with the amount of raw material (Eq.(29)). From these two values, the phenolic (Eq.(30)) and non-phenolic components (Eq.(31)) of the retained solids in the nanofiltration stage can be calculated.

$$
\begin{aligned}
& F_{C L A_{s S F}}=\left(\frac{3.31}{1000}\right) \cdot(0.4) \cdot \mathrm{F}_{\mathrm{RM}} \\
& F_{N E_{\text {sshmF }}}=0.02 \cdot 0.008 \cdot \mathrm{F}_{\mathrm{RM}} \\
& F_{R E N_{s s h m F}}=F_{C L A_{s F F}}-F_{N E_{s s h m F}} \\
& F_{R_{\text {sshm } N F}}=F_{R E N_{\text {sshm }}}-F_{R E N_{\text {sshmF }}}
\end{aligned}
$$

The non-phenolic components do not affect the dyeing process ${ }^{29}$. The pigment is dried with hot air up to $10 \%$ in water to be stored. The hot air is generated by an auxiliary process within the facility.

\subsection{Process 3: Production of power}

In this case, waste is stored for 3 days, reducing the amount of water from $60 \%$ to $10 \%{ }^{30}$. With this final amount of water, the heat of combustion of the spent coffee ground is $20 \mathrm{MJ} / \mathrm{kg}^{30}$. SCG is considered as a solid fuel (like coal) and it can have a yield of $40 \%$ to power (integrated gasification to combined cycle) 31. With this information and the price of the electricity, it is possible to estimate the income obtained from the sale of the produced power for the combustion of the spent coffee ground. A simplified flowsheet diagram of an integrated gasification and combined cycle can be seen in Figure 7. 


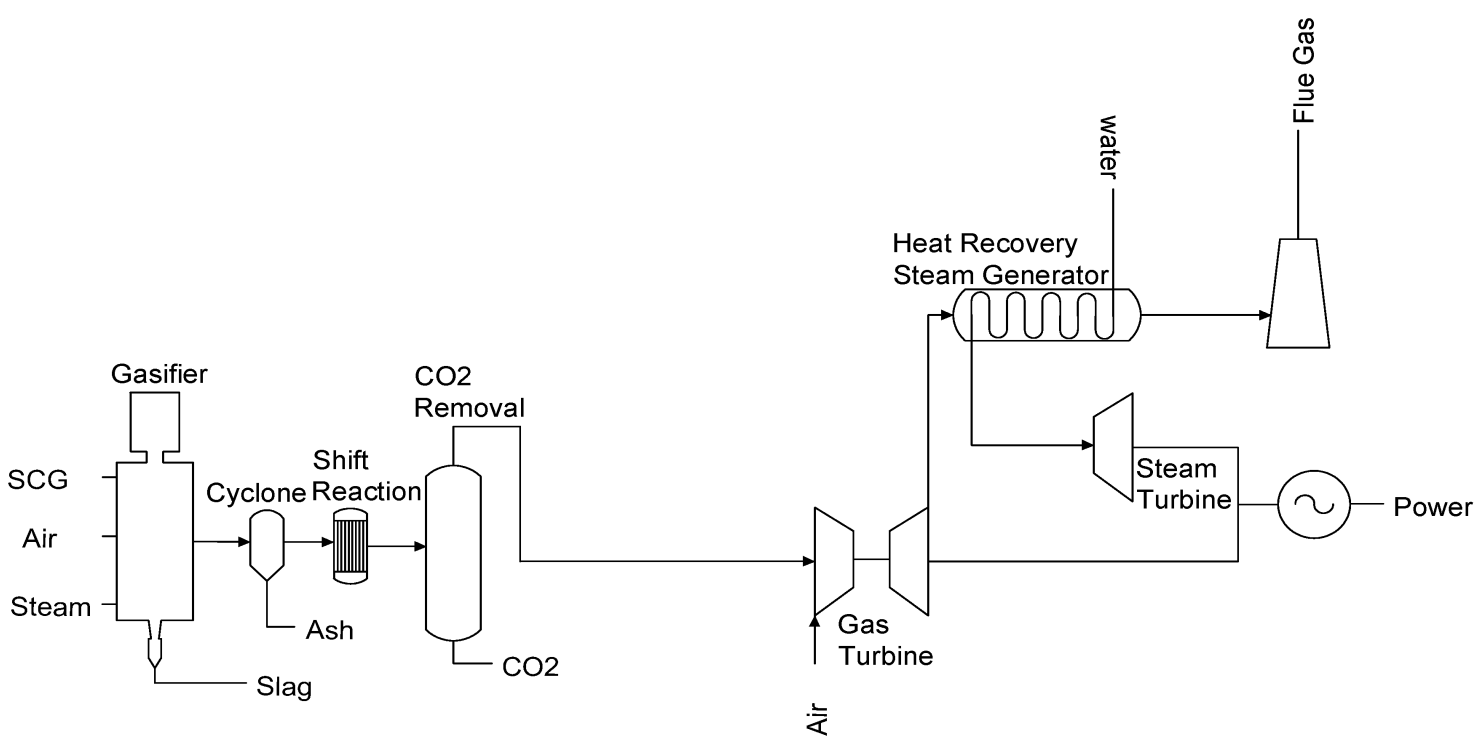

Figure 7.- Process flow diagram 3

\subsection{Auxiliary process. Production of hot air and steam}

It is necessary to produce hot air to carry out Process 1 and Process A2 since it is necessary to dry the natural extract and the natural pigment. A fraction of the SCG is sent to a boiler to produce steam and flue gas. To compute it, an energy balance is formulated. The composition of the flue gas is determined by stoichiometry ${ }^{32}$. The stoichiometry is shown in Eq. (32):

$$
C_{z} H_{y} O_{x}+r\left(z+\phi-\frac{x}{2}\right) O_{2}+r\left(\frac{79}{21}\right)\left(Z+\phi-\frac{x}{2}\right) N_{2} \rightarrow z C_{2}+2 \phi H_{2} O+r\left(\frac{79}{21}\right)\left(z+\phi-\frac{x}{2}\right) N_{2}+(r-1)\left(z+\phi-\frac{x}{2}\right) O_{2}
$$

Where $z, y$, and $x$ can be obtained from the elemental composition of the spent coffee ground ${ }^{33}, r$ is the excess air and $\phi$ corresponds to $y / 4$. To achieve the best ratio of excess air to yield of combustion, the excess air should be $1.7^{33}$. However, the air has humidity and, therefore, this equation has to be modified. $15 \%$ of the relative humidity and a temperature of $25^{\circ} \mathrm{C}$ are considered. The final equation is Eq.(33):

$$
\mathrm{C}_{0.3433} \mathrm{H}_{0.51} \mathrm{O}_{0.1335}+0.69 \mathrm{O}_{2}+2.584 \mathrm{~N}_{2}+3.372 \mathrm{H}_{2} \mathrm{O} \rightarrow 0.3433 \mathrm{CO}_{2}+3.6269 \mathrm{H}_{2} \mathrm{O}+2.584 \mathrm{~N}_{2}+0.283 \mathrm{O}_{2}
$$


It is necessary to compute the fraction of energy to produce steam and that used to obtain hot flue gas so that the energy balance holds. The $60 \%$ of the energy of the combustion is used to produce the steam, $30 \%$ to heat the flue gas and $10 \%$ of the energy is lost ${ }^{33}$. With this information, it is possible to obtain the mass and energy balances. The heat of combustion $(\mathrm{HC})$ of the SCG is $20 \mathrm{MJ} / \mathrm{kg}^{30}$. The energy balance applied to the combustion gases is shown by Eq.(34).

$$
\eta_{\text {air }} \cdot F_{S C G \rightarrow A U X} \cdot H C=\sum_{i} F_{i} \cdot c p_{i} \cdot\left(T_{o u t}-T_{\text {in }}\right)
$$

Where $\eta_{\text {air }}$ is the fraction of heat absorbed by the air, $\mathrm{F}_{\mathrm{SCG} \rightarrow \mathrm{AUX}}$ is the mass flow of burned raw material and $\mathrm{HC}$ is the heat of combustion. $\mathrm{m}_{\mathrm{i}}$ is the mass of each component of the flue gas, $\mathrm{Cp}_{\mathrm{i}}$ is the heat capacity, $T_{\text {in }}$ is the air inlet temperature and $T_{\text {out }}$ is the temperature of the flue gas. As the maximum amount of water that the air can remove is a function of its temperature and the amount of air, mass, and energy balances of the processes of combustion, and drying must be solved simultaneously.

No change in temperature is considered in the streams that are dried to avoid damaging the product. The heat supplied by flue gas must be equal to the heat required to dry the natural pigment up to $10 \%$ water and the natural extract up to $5.9 \%$. This energy balance is given by Eq. (35).

$$
\sum_{i} F_{i} \cdot c p_{i} \cdot\left(T_{\text {Out }_{F G}}-T_{\text {in }_{F G}}\right)=\lambda_{H 2 O} \cdot\left(F_{H 2 O_{I V}}-F_{H 2 O_{\text {OUT }}}\right)
$$

Where $T_{\text {in }}$ is the inlet temperature of the flue gas into the drying process, $T_{\text {out }}$ is the outlet temperature, $\lambda_{\mathrm{H} 2 \mathrm{O}}$ is the latent heat of water, $\mathrm{F}_{\mathrm{H} 2 \mathrm{O} \text { in }}$ is the mass flow of water of the stream that goes into the dryer and $\mathrm{F}_{\text {H2Oout }}$ is the mass flow of water of the stream that comes out. The evaporated water is removed by the flue gas, so its humidity increases with each of the two drying stages at process 1 and process A2. The relationship between absolute air humidity and partial pressure is indicated by Eq.(36). The relative humidity must be lower than one in the pigment drying process. Since this flue gas is generated through the combustion of SCG, to reduce the losses of raw material the target is to minimize its production. Therefore, the relative humidity of the flue gas from the last drying process is fixed to 1. 


$$
A H=0.625 \cdot \frac{P a}{P-P a}
$$

$\mathrm{AH}$ is the absolute humidity ( $\mathrm{kg}$ water $/ \mathrm{kg}$ dry air), $\mathrm{Pa}$ is the partial pressure of the water and $\mathrm{P}$ is the total pressure, 1 atm. Saturation pressure is calculated using Antoine's equation.

In addition to hot air production, steam is also produced. This steam is used to heat the streams before anaerobic digestion and the stream before the nanofiltration stage. The amount of steam generated is given by Eq. (37).

$$
\eta_{H 2 O} \cdot F_{S C G \rightarrow A U X} \cdot H C=F_{H 2 O} \cdot C p_{H 2 O} \cdot\left(120^{\circ} C-25^{\circ} C\right)+\lambda_{H 2 O} \cdot F_{H 2 O}
$$

Where $\eta_{\mathrm{H} 2 \mathrm{O}}$ is the percentage of heat absorbed by the water and $\mathrm{F}_{\mathrm{H} 2 \mathrm{O}}$ is the mass flow of steam generated. Note that $F_{S C G \rightarrow A U X}$ is the same variable as in Eq.(34). Since the amount of steam generated is much larger than the one necessary as a utility in the processes of the superstructure, the rest of the steam can be used in the extraction process of the instant coffee production. In the extraction process, the relationship between the steam and the solid total of the product is $\mathbf{2 8}$, according to a patent ${ }^{34}$. Besides, $75 \%{ }^{33}$ of the necessary energy to produce instant coffee is used in the extraction process. Therefore, it is possible to supply a part of that energy with the steam of the auxiliary process. As a result, the circular economy and the principle of self-sufficiency are favored.

\subsection{Process using dried raw material}

The most studied process that uses dried SCG is the biodiesel production process, but the raw material has $60 \%$ of water and it is necessary to remove that water before feeding the process. For this reason, it is very likely that this type of process is not economically feasible. Therefore, a preliminary study is carried out to determine the maximum income and energy that can be obtained from that biodiesel. The results of that studio are that the energy balance is negative, $4698 \mathrm{kcal}$ per $100 \mathrm{~kg} \mathrm{scG}_{\text {, }}$ due to the yield to produce the biodiesel and the difference between the heat combustion of the SCG and Biodiesel. A quick economic 
evaluation also shows non-profitable production, $0.9 €$ per ton of Biodiesel. Both studies are reported in the supplementary material.

\subsection{Solution Procedure}

\subsection{1.-Process design}

The superstructure is solved using a simplified profit as an objective function. The amount of SCG that is sent to each process is a variable of the optimization model and will depend on the operating costs and incomes from the sale of the products generated in each process. The objective function is given by Eq. (38). including the income from products and the cost of raw material and energy.

$$
\begin{aligned}
& \text { Pr ofit }=\sum_{p} \text { PriceProduct }_{\mathrm{p}} \cdot F_{p}-\sum_{i} \text { PriceRawMaterial }_{i} \cdot F_{i}-\mathrm{CW}-\mathrm{CE} \\
& -\mathrm{C}_{\text {PowerPlant }} \cdot \mathrm{HC} \cdot F_{S C G \rightarrow P 3}
\end{aligned}
$$

Where $F_{i}$ and $F_{p}$ are the mass flow of the raw material and products, respectively. $F_{S c G} \rightarrow P_{3}$ is the amount of spent coffee ground that is sent to Process 3. CE and CW are the production cost of the electrical and thermal energy, respectively. PowerPlant $_{\text {is the }}$ operating cost of the power plant.

\section{Cost of Raw Material}

We consider the cost of the spent coffee ground, citric acid, and the water. The prices can be seen in Table 2.

Table 2.- Price of the raw material

\begin{tabular}{|c|c|}
\hline Raw material & Cost $(€ / \mathbf{t})$ \\
\hline Spent Coffee Ground ${ }^{4}$ & 50 \\
\hline Citric Acid $35^{35}$ & 530 \\
\hline Water $^{36}$ & 0.78 \\
\hline
\end{tabular}

\section{Cost of energy}

Both electrical and thermal energy are considered. On the one hand, most of the electrical energy used in the plant is consumed by the pumps necessary to feed the processes of reverse osmosis ( 20 bars) and 
nanofiltration ( 5 bars). For the calculation of this type of energy, the power equation of a pump is applied to the case of the nanofiltration(Eq. (39)) and reverse osmosis (Eq. (40)).

$$
\begin{gathered}
P w_{N F}=n_{N F} \cdot p_{H 2 O} \cdot g \cdot V_{C L A} \cdot h_{N F} \\
P w_{I O}=n_{I O} \cdot p_{H 2 O} \cdot g \cdot V_{P E R} \cdot h_{I O}
\end{gathered}
$$

Where $n_{b}$ is the efficiency of the pump ( 0.55 for the nanofiltration process and 0.47 for the reverse osmosis process ${ }^{37}$ ) and $h_{b}$ is the hydraulic height that is computed performing an energy balance, the Bernoulli theorem, to the pump resulting in values of $41.37 \mathrm{~m}$ and $165.43 \mathrm{~m}$ for nanofiltration and reverse osmosis process, respectively. Considering that the electrical energy is produced in the plant using raw material, the cost of electricity will be equal to the cost of the raw material used to produce that energy. Taking into account the considerations indicated in section 2.4 and the cost of the raw material, the cost of the energy consumed by the reverse osmosis and nanofiltration processes can be estimated by Eq. (41).

$$
C W=\left(\mathrm{Pw}_{\mathrm{Nano}}+\mathrm{Pw}_{\mathrm{OI}}\right) \cdot \tau \cdot \mathrm{HC} \cdot 0.4 \cdot \mathrm{F}_{\mathrm{RM}} \cdot \mathrm{C}_{\mathrm{RM}}
$$

Where $\tau$ is the operation time of the pump, whose value is a year and $C_{R M}$ is the cost of the spent coffee ground.

On the other hand, most of the thermal energy used in the plant is used in the drying processes for the production of the natural extract (Process 1 ) and the natural pigment (Process A2). The value corresponds to the energy required to evaporate the water accompanying both products. Its cost is computed as the amount of SCG needed to produce the energy. In this way, the heat energy cost to dry the natural pigment and the natural extract are calculated by Eq.(42) and Eq.(43). The total cost is given by Eq.(44)

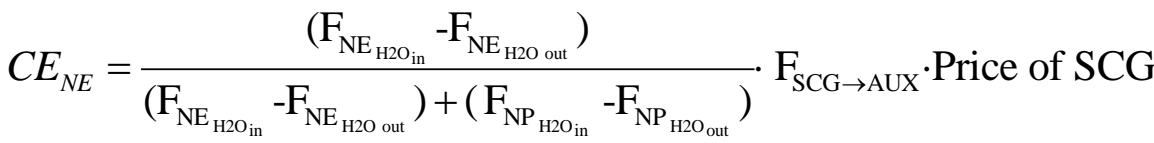

$$
\begin{aligned}
& C E_{N P}=\frac{\left(\mathrm{F}_{\mathrm{NP}_{\mathrm{H} 20_{\text {in }}}}-\mathrm{F}_{\mathrm{NP}_{\mathrm{H} 20 \text { out }}}\right)}{\left(\mathrm{F}_{\mathrm{NE}_{\mathrm{H}_{2} \text { in }}}-\mathrm{F}_{\mathrm{NE}_{\mathrm{H} 20 \text { out }}}\right)+\left(\mathrm{F}_{\mathrm{NP}_{\mathrm{H}_{2} \mathrm{O}_{\text {in }}}}-\mathrm{F}_{\left.\mathrm{NP}_{\mathrm{H} 20_{\text {out }}}\right)}\right)} \cdot \mathrm{F}_{\mathrm{SCG} \rightarrow \mathrm{AUX}} \cdot \text { Price of SCG }
\end{aligned}
$$




$$
C E=C E_{N E}+C E_{N P}
$$

Operating cost of the power plant.

It is possible to estimate the operating costs of a power plant from biomass using data from the references. If the capacity of the plant is between $10 \mathrm{MW}$ and $100 \mathrm{MW}$, the operational costs are given by Eq. $(45)^{38}$.

$$
C_{\text {PowerPlant }}=100 \$ / \mathrm{kW}
$$

Income from the products

The income of the natural extracts, natural pigment, biogas, digestate, and power are considered.

-In the case of natural extracts, the same price as the reference (70€/kg natural extracts) is used ${ }^{4}$.

-It is considered that the biogas is used to produce power, therefore, its price is estimated using the price of the power $\left(0.1021 € / \mathrm{kWh}{ }^{39}\right.$, the yield to produce power from a gas fuel $\left(40 \%{ }^{40}\right)$ and heat of combustion of $5500 \mathrm{kcal} / \mathrm{m}^{3}{ }^{38}$. The income of the digestate is estimated using the price of fertilizer (182.16€/t $\left.{ }^{41}\right)$.

-Following the classification criteria of natural pigments used by a company specialized in the sale of this type of product ${ }^{42}$, the main factor used to estimate the prices of these is the weight of fiber (WOF) ${ }^{43}$. WOF is calculated following the Eq. (46).

$$
\text { WOF }=\frac{\text { Weight Natural Pigment }}{\text { Weight Textile Sample }} \cdot 100
$$

In the case or the natural pigment of this work, the relation is $0.78 \mathrm{~g}$ Natural Pigment $/ \mathrm{g}$ textile and, therefore, the WOF is $78 \%$. The price of this product can be estimated using a similar natural pigment ${ }^{42}$, whose sale price is $28 € / \mathrm{kg}$. 
-Finally, the price of the power and the yield, that are indicated in section 2.4 , are used to estimate the income of the power produced using the SCG that is sent to the process 3.

The optimization formulation is subjected to the models described in sections 2.1-2.5.

\subsection{2.- Investment and production costs of the factory}

The investment and production costs associated with the use of SCG as raw material are estimated using the factorial method (Sinnot, 2005). The investment cost is based on the equipment cost that is computed unit by unit from their size and using cost correlations appropriated to each unit type. The production costs involve raw materials, maintenance, labor among others. Further considerations and calculations are included in the supplementary material.

\section{Results}

One of the main problems in the development of biorefineries aimed at treating this type of waste is the decentralization of its production. Approximately $50 \%$ of the SCG is generated in cafes, restaurants and private consumption ${ }^{9}$ and its collection is challenging because individual production is very low. The high content of water and organic matter makes its transport and storage also a difficult task, due to the degradation processes. The other $50 \%$ is generated in the processes of soluble coffee production. In addition, the performance also depends on the quantity and quality of the raw material sent to the biorefinery, so it is important to enssure that the raw material for the biorefinery is homogeneous in both quality and quantity. Therefore, it is assumed that the processing of SCG will be an additional section to the soluble coffee production process. In this way, the initial conditions of the waste will not vary significantly. The standard size of a soluble coffee production plant varies between 16500 and 23000 tons per year ${ }^{5}$. Therefore, a production of $40000 \mathrm{t} / \mathrm{year}(2 \mathrm{~kg}$ of SCG are produced by $1 \mathrm{~kg}$ of soluble coffee produced ${ }^{4}$ ) is used to test the methodology explained in section 2 . The results are divided into two sections. The results corresponding to the mass and energy balances of the process selected as optimal and the economic evaluation of each of the processes.

\subsection{Mass and Energy Balances.}

All the processes previously described are considered simultaneously in the same optimization model. The amount of SCG sent to each process is a variable of the problem. The results show that $62.57 \%$ of the raw 
material is sent to Process 1 while $37.43 \%$ is used for the production of utilities for the process. This amount is the minimum necessary to generate hot air for the drying processes. The yield of natural extract production is $0.525 \%$ while that of natural pigment is $5.5 \%$ (with respect to the initial spend coffee ground). The yield to natural extract is slightly lower than the one indicated in the literature ${ }^{44}(0.8 \%)$. Nevertheless, this is due to the fact that part of the SCG is being used to produce energy and the yield is calculated considering the entire amount of SCG (40000t). The biogas and digestate production yields are $3 \%$ and $12 \%$, respectively. Table 3 shows a summary of the major results.

It can be seen that the larger the added value to a product, the lower its yield. The product that shows the best trade-off is the natural pigment since its price is high and the yield is not particularly low. In the opposite case, the biogas, with low yield and low price.

The water reused within the process allows a reduction in the consumption of water of $32 \%$. The output water from the digestate filtration process could have been used in the scrubber (see Figure 1), however, the dissolved ammonia did not allow it since, in this case, the consumption of water would be 3 times larger. By using a fraction of SCG as fuel, the use of electrical energy that may come from non-renewable sources is avoided. In addition, it is observed that the amount of steam generated in the plant is much larger than what is necessary (only $7 \%$ is used by the new line of the factory). This is because the consumption of the boiler is adjusted to produce the flue gas necessary for the drying processes, while the steam generated is considered as a secondary asset (see eq. (33)). Therefore it is possible to use this steam to supply the heating utility for the extraction process of the production of instant coffee. The excess of steam produced from the SCG represents $9.5 \%$ of the total steam required in the extraction process. Since the extraction process represents $75 \%$ of the energy of the entire instant coffee production process, the steam generated in the auxiliary process allows saving $7 \%$ of the total energy. As a result of the integration of the use of SCG within a soluble coffee facility, $7925 \mathrm{tCO}_{2} /$ year can be saved versus the use of natural gas ${ }^{45}$ or $18328 \mathrm{tCO}_{2}$ / year if the steam is generated with coal ${ }^{38}$. The amount of SCG needed to generate all the steam needed to supply the extraction process for soluble coffee would be 186667t. Therefore, the maximum amount of steam savings that can be achieved, assuming that all the SCG generated in the soluble coffee production process is sent to the boiler, would be $21.5 \%$. 


\begin{tabular}{|c|c|}
\hline Products & Amount (t/year) \\
\hline Dried natural extract & 210 \\
\hline Dried natural Pigment & 2218 \\
\hline Biogas & 1171 \\
\hline Digestate & 4687 \\
\hline Steam & 55188 \\
\hline Raw material & Amount (t/year) \\
\hline Total SCG & 40000 \\
\hline SCG for the process 1 & 25028 \\
\hline SCG for the process 2 & 0 \\
\hline SCG for the process 3 & 0 \\
\hline SCG for the auxiliary process & 14972 \\
\hline Consumed water (With water integration) & 141122 \\
\hline Consumed water (Without water integration) & 207769 \\
\hline Citric Acid & 344 \\
\hline Steam & 4280 \\
\hline Air for the combustion process & 316000 \\
\hline
\end{tabular}

\subsection{Economic Evaluation}

The income and costs considered by the objective function determine the transformation route that is the most profitable. Once the best process is established, a more detailed economic evaluation is carried out. As indicated in the previous section, most of the available raw material is sent to Process 1 , so this is the best process from an economic point of view. Table 4 shows the results of income and cost considered in the objective function for Process 1. On the one hand, the products that generate the largest income from Process 1 are the natural extract and the natural pigment, which represent $20.6 \%$ and $77.9 \%$ of the total income respectively. This is because both are highly added valued products, despite the low amount produced. The waste produced in a decanter is used to produce biogas and digestate. Even though, the income of these products is low, representing $0.2 \%$ and $1.2 \%$ of the total, respectively. On the other hand, the highest operating cost is associated with the raw material, representing $65.7 \%$ of total operational costs, while the citric acid represents $9.56 \%$, the water $5.6 \%$, and the energy $19 \%$. This is because the amount of citric acid used is very small, water is a cheap chemical compound, and the energy consumption is not very high. In addition, we reduce the consumption of energy in the drying process through the pre-filtering process and the hot air, steam and power are produced at the factory. 


\begin{tabular}{|c|c|}
\hline Item & (k€/year) \\
\hline Income of pigment & 55574 \\
\hline Income of natural extract & 14689 \\
\hline Income of digestate & 853 \\
\hline Income of biogas & 142 \\
\hline Total income & 71258 \\
\hline Cost of raw material & 1251 \\
\hline Cost of citric acid & 182 \\
\hline Cost of water & 110 \\
\hline Cost of heat energy & 357 \\
\hline Cost of electric energy & 3 \\
\hline Main variable operating costs & 1903 \\
\hline
\end{tabular}

A complete economic analysis, considering operational costs and fixed capital, is carried out for Process 1 , since this process is the most profitable. Table 5 shows the results of the detailed economic analysis.

The operating costs considered by the objective function represent almost $45 \%$ of the total operating costs. It is necessary to consider that some costs, such as operating labour and laboratory costs will be similar in all the processes considered. In addition, there is a large difference in the profits obtained among the set of processes involved in the superstructure, therefore, the objective function is considered to correctly select the most profitable process.

On the one hand, regarding the investment costs, the highest share corresponds to the cost of the digesters, which represents $47 \%$ of the total, because of the high residence time necessary for the conversion of the waste into biogas and digestate. First, the possibility of not treating these wastes was considered to avoid the cost of the digesters, but one of the objectives of this work is to use all the wastes produced in the processes (that can be treated) towards implementing the circular economy concept within the food industry aiming at zero waste emissions. Therefore, that cost was considered in the analysis. On the other hand, regarding the operating costs, the highest is the cost of raw material, which represents about $34 \%$ of total costs. Noted that the income from the sale of the products allows to recover the investment in the first year of installation. This is because of the price used to estimate the income of the products is the final price in a retail establishment. It is expected that the manufacturing price and the final sale price differ considerably, however, this price is considered an industrial secret and is very difficult to estimate. 
Table 5.- Results of the complete economic analysis

\begin{tabular}{|c|c|}
\hline \multicolumn{2}{|c|}{ Total investment(M€) } \\
\hline PCE & 4.08 \\
\hline PPC & 9.60 \\
\hline Fixed Capital & 13.44 \\
\hline Working Capital & 0.67 \\
\hline Total & 14.1 \\
\hline \multicolumn{2}{|c|}{ Operation Cost(M€/year) } \\
\hline \multicolumn{2}{|c|}{ Variable } \\
\hline Raw materials & 1.43 \\
\hline Miscellaneous & 0.07 \\
\hline Utilities & 0.11 \\
\hline Power & 0.36 \\
\hline \multicolumn{2}{|c|}{ Fixed } \\
\hline Maintenance & 0.67 \\
\hline Operating Labour & 0.08 \\
\hline Plant overheads & 0.04 \\
\hline Laboratory & 0.02 \\
\hline Capital Charges & 1.34 \\
\hline Insurance & 0.13 \\
\hline Total & 4.25 \\
\hline $\begin{array}{c}\text { Annual } \\
\text { profit(M€/year) }\end{array}$ & 66.87 \\
\hline
\end{tabular}

3.3 Alternative solutionslt is possible to process the SCG following also processes 2 and 3 . While the optimization does not select these alternatives based on poorer economic potential, in this section the economic performance of Process 1 is compared with other processes proposed in this study is presented. The amount sent to each process was set to analyse the maximum benefits that the factory would have if other processes were selected. An economic evaluation of Process 2 and 3 can be seen in Table 6.

In the case of Process 2, the operating costs are similar to the income and, therefore, the profit is low. In fact, the profit is almost 300 times lower than the profit of Process 3 and 3000 times lower than the profit of Process 1. In addition, it is necessary to indicate that the amortization costs of the equipment for each process are not being considered when selecting the processes. If this cost is added in the economic 
evaluation, this process would not be profitable, and it would be necessary to discard it when carrying out a more detailed analysis of each of the processes. However, unlike what happened with diesel, which can be determined not to be competitive with a preliminary study, in this case, the difference between incomes and costs is quite small and cannot be discarded in a preliminary study.

Finally, Process 3 is economically viable but its profit is worse than Process 1, 10 times less. Since the power factories that using biomass in Europe usually have a capacity between 10 and $100 \mathrm{MW}{ }^{38}$ and the factory considered in this work has a power production of $11.21 \mathrm{MW}$, and therefore, the estimation of the operational costs explained in Section 2.7 is considered correct.

\section{Table 6.- Economic evaluation of the Process 2 and 3}

\begin{tabular}{|c|c|}
\hline \multicolumn{1}{|c|}{ Process 2 } & (k€/year) \\
\hline Item & 226.334 \\
\hline Income of biogas & 1957.559 \\
\hline Income of digestate & 2184 \\
\hline Total income & 2000 \\
\hline Cost of raw material & 162 \\
\hline Cost of water & 2162 \\
\hline Operational total cost & $\mathbf{2 2}$ \\
\hline Profit of the process 2 & \\
\hline Process 3 & (k€/year) \\
\hline Item & 9100 \\
\hline Incomes of power & 800 \\
\hline Operational total cost & 2000 \\
\hline Cost of raw material & 2800 \\
\hline Operational total cost & $\mathbf{6 3 0 0}$ \\
\hline Profit of the process 3 &
\end{tabular}

\section{Conclusions}

The analysis of the use of SCG as a resource to produce added-value products and energy has been analyzed from the process perspective within a biorefinery concept. A superstructure has been developed where 3 different processes are considered to produce 5 products (dry natural extract, natural pigment for the textile industry, biogas, digestate and power). Mathematical optimization techniques are used to select the best process and the portfolio of products from an economic point of view. In addition, the integration of energy and water is considered. Due to the decentralized production of the spent coffee ground and its 
high water content, it was decided that the process is integrated as an additional production line to the soluble coffee production process and a fraction of the remaining energy of the recovery process is used to drive the main production process.

After analyzing different alternatives, two processes are economically viable, the production of energy, Process 3 , and the production of natural extract and pigment, Process 1 . Nevertheless, Process 1 shows a profit 10 times higher due to the high sale price of the natural pigment and of the natural extract and therefore, this process is chosen for the valorization of the SCG. Between these two products, the income from the sale of natural pigments is 3.8 times higher than the natural extract, which makes natural pigment the most balanced product in terms of price and production capacity. The annual profit using Process 1 is $67 \mathrm{MM} € /$ year while operating costs are 4.25 MM €/year. Regarding investment costs, $14.1 \mathrm{MM} €$ are necessary to start up the new production line based on Process 1. The digesters are the most expensive equipment (48\% of the total equipments cost), nevertheless, they are necessary for the treatment of the waste produced in the decantation process. The treatment of these wastes was maintained to comply with the treatment of all the wastes generated since the benefits of the sale of digestate and biogas $(0.85$ $\mathrm{MM} € /$ year and $0.142 \mathrm{MM} € /$ year, respectively) are negligible compared to other products.

The use of SCG to produce biodiesel is discarded due to the need to dry the raw material. Digestate and biogas production using the SCG as raw material (Process 2) is discarded because it has a negative benefit when all operating costs are considered.

\section{Acknowledgments}

The authors acknowledge the funding received from the European Union's Horizon 2020 research and innovation programme under the Marie Sklodowska-Curie grant agreement No 778168 . MT acknowledges JCyL for a PhD fellowship. M.L.C thanks the CNPq, grant numbers 305393/2016-2, and Fundação Araucária - grant agreement 004/2019

\section{Reference}

(1) European Comission. What is Horizon 2020? | Horizon 2020 https://ec.europa.eu/programmes/horizon2020/en/what-horizon-2020 (accessed Jun 2, 2020).

(2) Bustamante, J.; van Stempvoort, S.; García-Gallarreta, M.; Houghton, J. A.; Briers, H. K.; Budarin, V. L.; Matharu, A. S.; Clark, J. H. Microwave Assisted Hydro-Distillation of Essential Oils from Wet Citrus Peel Waste. Journal of Cleaner Production 2016, 137, 598-605. https://doi.org/10.1016/j.jclepro.2016.07.108. 
(3) Criado, A.; Martín, M. Integrated Multiproduct Facility for the Production of Chemicals, Food, and Utilities from Oranges. Industrial \& Engineering Chemistry Research 2020, 59 (16), 7722-7731. https://doi.org/10.1021/acs.iecr.0c00476.

(4) Brazinha, C.; Cadima, M.; Crespo, J. G. Valorisation of Spent Coffee through Membrane Processing. Journal of Food Engineering 2015, 149, 123-130. https://doi.org/10.1016/j.jfoodeng.2014.07.016.

(5) Murthy, P. S.; Madhava Naidu, M. Sustainable Management of Coffee Industry By-Products and Value Addition - A Review. Resources, Conservation and Recycling. Elsevier September 1, 2012, pp 45-58. https://doi.org/10.1016/j.resconrec.2012.06.005.

(6) International Coffee Organization. International Coffee Organization - What's New http://www.ico.org/ (accessed Jun 2, 2020).

(7) Rajesh, J.; Kavitha, S.; Yukesh, R.; Dinesh, M.; Preethi; Atabani, A. E.; Kumar, G. Biorefinery of Spent Coffee Grounds Waste: Viable Pathway towards Circular Bioeconomy. Bioresource Technology 2020, 302, 122821. https://doi.org/10.1016/j.biortech.2020.122821.

(8) Pfluger, R. A. Soluble Coffee Processing. Solid Wastes Origin Collection Processing \& Disposal. C.I. Mantell 1975.

(9) Cruz, R.; Cardoso, M. M.; Fernandes, L.; Oliveira, M.; Mendes, E.; Baptista, P.; Morais, S.; Casal, S. Espresso Coffee Residues: A Valuable Source of Unextracted Compounds. Journal of Agricultural and Food Chemistry 2012, 60 (32), 7777-7784. https://doi.org/10.1021/jf3018854.

(10) Kwon, E. E.; Yi, H.; Jeon, Y. J. Sequential Co-Production of Biodiesel and Bioethanol with Spent Coffee Grounds. Bioresource Technology 2013, 136, 475-480.

https://doi.org/10.1016/j.biortech.2013.03.052.

(11) Kondamudi, N.; Mohapatra, S. K.; Misra, M. Spent Coffee Grounds as a Versatile Source of Green Energy. Journal of Agricultural and Food Chemistry 2008, 56 (24), 11757-11760. https://doi.org/10.1021/jf802487s.

(12) Vitěz, T.; Koutný, T.; Šotnar, M.; Chovanec, J. On the Spent Coffee Grounds Biogas Production. Acta Universitatis Agriculturae et Silviculturae Mendelianae Brunensis 2016, 64 (4), 1279-1282. https://doi.org/10.11118/actaun201664041279.

(13) Ktori, R.; Kamaterou, P.; Zabaniotou, A. Spent Coffee Grounds Valorization through Pyrolysis for Energy and Materials Production in the Concept of Circular Economy. In Materials Today:

Proceedings; Elsevier Ltd, 2018; Vol. 5, pp 27582-27588.

https://doi.org/10.1016/j.matpr.2018.09.078.

(14) Kamil, M.; Ramadan, K. M.; Olabi, A. G.; Shanableh, A.; Ghenai, C.; al Naqbi, A. K.; Awad, O. I.; $\mathrm{Ma}, \mathrm{X}$. Comprehensive Evaluation of the Life Cycle of Liquid and Solid Fuels Derived from Recycled Coffee Waste. Resources, Conservation and Recycling 2019, 150, 104446. https://doi.org/10.1016/j.resconrec.2019.104446.

(15) Shi, L. Bioactivities, Isolation and Purification Methods of Polysaccharides from Natural Products: A Review. International Journal of Biological Macromolecules 2016, 92, 37-48. https://doi.org/10.1016/j.jpbiomac.2016.06.100.

(16) Ribeiro, H.; Marto, J.; Raposo, S.; Agapito, M.; Isaac, V.; Chiari, B. G.; Lisboa, P. F.; Paiva, A.; Barreiros, S.; Simões, P. From Coffee Industry Waste Materials to Skin-Friendly Products with Improved Skin Fat Levels. European Journal of Lipid Science and Technology 2013, 115 (3), 330336. https://doi.org/10.1002/ejt.201200239. 
(17) Low, J. H.; Rahman, W. A. W. A.; Jamaluddin, J. The Influence of Extraction Parameters on Spent Coffee Grounds as a Renewable Tannin Resource. Journal of Cleaner Production 2015, 101, 222-228. https://doi.org/10.1016/j.jclepro.2015.03.094.

(18) Obruca, S.; Benesova, P.; Petrik, S.; Oborna, J.; Prikryl, R.; Marova, I. Production of Polyhydroxyalkanoates Using Hydrolysate of Spent Coffee Grounds. Process Biochemistry 2014, 49 (9), 1409-1414. https://doi.org/10.1016/j.procbio.2014.05.013.

(19) Liu, K.; Price, G. W. Evaluation of Three Composting Systems for the Management of Spent Coffee Grounds. Bioresource Technology 2011, 102 (17), 7966-7974. https://doi.org/10.1016/j.biortech.2011.05.073.

(20) Ciesielczuk, T.; Karwaczyńska, U.; Sporek, M. The Possibility of Disposing of Spent Coffee Ground with Energy Recycling. Journal of Ecological Engineering 2015, 16 (4), 133-138. https://doi.org/10.12911/22998993/59361.

(21) Mussatto, S. I.; Moncada, J.; Roberto, I. C.; Cardona, C. A. Techno-Economic Analysis for Brewer's Spent Grains Use on a Biorefinery Concept: The Brazilian Case. Bioresource Technology 2013, 148, 302-310. https://doi.org/10.1016/j.biortech.2013.08.046.

(22) Martin, M. Industrial Chemical Process Analysis and Design; Elsevier, 2016.

(23) Telis-Romero, J.; Gabas, A. L.; Polizelli, M. A.; Telis, V. R. N. Temperature and Water Content Influence on Thermophysical Properties of Coffee Extract. International Journal of Food Properties 2000, 3 (3), 375-384. https://doi.org/10.1080/10942910009524642.

(24) Sikka, S. S.; Bakshi, M. P. S.; Ichhponani, J. S. Evaluation in Vitro of Spent Coffee Grounds as a Livestock Feed. Agricultural Wastes 1985, 13 (4), 315-317. https://doi.org/10.1016/01414607(85)90057-5.

(25) Campos-Vega, R.; Loarca-Piña, G.; Vergara-Castañeda, H. A.; Dave Oomah, B. Spent Coffee Grounds: A Review on Current Research and Future Prospects. Trends in Food Science and Technology. Elsevier Ltd September 1, 2015, pp 24-36. https://doi.org/10.1016/j.tifs.2015.04.012.

(26) Pedras, B. M.; Nascimento, M.; Sá-Nogueira, I.; Simões, P.; Paiva, A.; Barreiros, S. SemiContinuous Extraction/Hydrolysis of Spent Coffee Grounds with Subcritical Water. Journal of Industrial and Engineering Chemistry 2019, 72, 453-456.

https://doi.org/10.1016/j.jiec.2019.01.001.

(27) Taifouris, M. R.; Martín, M. Multiscale Scheme for the Optimal Use of Residues for the Production of Biogas across Castile and Leon. Journal of Cleaner Production 2018, 185, 239-251. https://doi.org/10.1016/j.jclepro.2018.03.018.

(28) Martín-Hernández, E.; Guerras, L. S.; Martín, M. Optimal Technology Selection for the Biogas Upgrading to Biomethane. Journal of Cleaner Production 2020, 267, 122032.

https://doi.org/10.1016/j.jclepro.2020.122032.

(29) Koh, E.; Hong, K. H. Preparation and Properties of Wool Fabrics Dyed with Spent Coffee Ground Extract. Textile Research Journal 2019, 89 (1), 13-19. https://doi.org/10.1177/0040517517736469.

(30) Kang, S. B.; Oh, H. Y.; Kim, J. J.; Choi, K. S. Characteristics of Spent Coffee Ground as a Fuel and Combustion Test in a Small Boiler (6.5 KW). Renewable Energy 2017, 113, 1208-1214. https://doi.org/10.1016/j.renene.2017.06.092.

(31) Gonzalez, J. M. Instituto Nacional de Electricidad y Energías Limpias | Gobierno | gob.mx https://www.gob.mx/ineel\#documentos (accessed Jun 2, 2020). 
(32) Roman, M.; Bobaşu, E.; Selişteanu, D. Modelling of Biomass Combustion Process. In Energy Procedia; Elsevier Ltd, 2011; Vol. 6, pp 432-440. https://doi.org/10.1016/j.egypro.2011.05.050.

(33) Silva, M. A.; Nebra, S. A.; Machado Silva, M. J.; Sanchez, C. G. The Use of Biomass Residues in the Brazilian Soluble Coffee Industry. Biomass and Bioenergy 1998, 14 (5-6), 457-467. https://doi.org/10.1016/S0961-9534(97)10034-4.

(34) Pedersen, A. H.; Sorensen, J. K.; Haraldsted, H. Production of an Instant Coffee Product in High Yield. Wo 2016/004949 Al. WO 2016/004949 Al, July 8, 2014.

(35) ECHEMI. Citric Acid Anhydrous Price Market Analysis https://www.echemi.com/productsInformation/pd20150901044-citric-acid-anhydrous.html (accessed Sep 3, 2020).

(36) Trata Brasil: Saneamento é saúde. Rankinng Do Saneamento 2020; 202AD.

(37) Sinnott, R. K. Chemical Engineering Design: Chemical Engineering Design v.6: Chemical Engineering Design Vol 6, 4th Revise.; Butterworth-Heinemann Ltd: Amsterdam; Heidelberg u.a., 2005.

(38) International Renewable Energy Agency ( IRENA). Biomass for Heat and Power. 2015.

(39) Organismo Supervisor de la Inversion en Energía y Minería. Tarifas eléctricas industriales y comerciales en Latino América https://observatorio.osinergmin.gob.pe/tarifas-electricasindustriales-comerciales-latinoamerica (accessed Jun 2, 2020).

(40) Asís, H. G.; Dopazo, F.; Gianoglio, P. J. Producción de Energía a Partir de Biogás Obtenido de Residuos Sólidos Urbanos. Universidad Tecnológica Nacional 2012.

(41) Ama Brasil. Evolução de preços de Fertilizantes https://amabrasil.agr.br/web/portfolioitem/evolucao-de-precos-de-fertilizantes/ (accessed Jun 2, 2020).

(42) Maiwa. Maiwa Online Store https://maiwa.com/ (accessed Jun 2, 2020).

(43) Maiwa. The Maiwa Guide to Natural Dyes https://naturaldyes.ca/s/guide_to_natural_dyes.pdf (accessed Jun 2, 2020).

(44) Serrano Rico, J. C.; Carranza Sánche, Y. A. Analisis Teórico de La Combustión En Quemadores de Gas Natural. Scientia et Technica 2005, 11 (29), 139-143.

(45) Junta de Castilla y León. Tipos de carbón https://energia.jcyl.es/web/es/biblioteca/tiposcarbon.html (accessed Jun 4, 2020). 